Vol. XXIII No $1 \quad 2017$

\title{
LEADERSHIP IN THE PROCESS OF COMMAND AND CONTROL, PLACE AND ROLE OF COMMANDER-MANAGER
}

\author{
Milan PODHOREC, Pavel HRINÍK, Gustav LAKOŠ \\ University of Defence, Brno, The Czech Republic \\ milan.podhorec@unob.cz, pavel.hrinik@unob.cz,gustav.lakos@unob.cz
}

\begin{abstract}
The paper clarifies the place and role of a commander as a manager in the process of command and control. It explained the concept of the competences model that the commander should possess. The authors define the basic requirements for the capabilities of all military professionals. The paper focused on the commander manager s ability to actively and creatively adapt to changing environment as well as on the ability to regulate negative psychological impacts. Emphasis is placed also on the ability to make decisions in uncertainty and on the ability to regulate commander's internal and external activity due to the current situation.
\end{abstract}

Keywords: leadership, management, competences, communication, organization

\section{Introduction}

The mission of managerial approach is to give managers quantitative basis for decision making with regards to operations and activities which fall under their command. Managerial science is occupied with the description, recognition and prediction of complex social systems (people and objects) which operate in natural environment. Ideas and conceptions of managerial science basically represent certain extensions of scientific management which are parts of classic approach. The purpose of managerial science is to give managers quantitative and qualitative basis for decision making.

Managerial scientists emphasize mathematic modelling of systems. During the times of war, operational experts successfully overcame a number of military problems including logistical tasks and search for optimal command and control strategy of a military operation. It is very difficult to unambiguously distinguish clear outlines of managerial science process, but it is possible to identify its characteristic features. It is therefore possible to say that the majority of instruments and techniques used in managerial science are marked by:
Primary focus on decision making. Main result of an analysis must have direct exercise in managerial operations. Decision making is still central activity of today's commanders and managers of all degrees of management.

Relying on economic effectiveness criteria. The comparison of alternative options is to be based on measurable values pointing at future consequences of a decision (options of the enemy and own forces, competition etc.)

Relying on formal mathematical models. Mathematical models represent a description of presented problem and allow for finding its solution. Method for finding the solution has to be explicit enough, so that any other solver can use it to reach accordant solution. Requirement of repeatability is also typical for scientific (behavioural) approach to management. In reality, repeatability is typical for all scientific analyses.

Dependence on computers. This dependence results from the complexity of mathematical model application, the amount of processed data or large number of mathematical operations in objective lack of time.

It is also important to formulate competencies of military professionals, specifically commanders who are responsible for command 
and control process in units and installations of the Army of the Czech Republic.

\section{Commander as a manager - role, assignment, competences}

Commander has to solve problems regarding with planning, organising, coordination, leadership and control during daily activities and duties. Commander has to apply managers' functions also in possible conditions of computer absent during battle. Mathematical models can managers functions/roles substantially make easy. Modern and smart commanders must fulfil 3 basic managers' tasks outgoing from 3 basic approaches to management supplemented by systematic and contingent approach:

- Manage organization,

- Manage employees,

- Manage preparation a conducting of operation.

Managerial and executive staff of each organization in disregard of what is matter of business is in interference with those tasks of leading. It must be studied and executed everywhere we want to gain upon rivalry (enemy) in its activity.

Managers must primarily rely on knowledge coming from classical approach of leading of work and organizations. For the leading of people they need behavioural knowledges and for the operation control is useful knowledges form management science.

Modern approach of leading, asserted from the managers' level in face of subordinated management (certain group of employees, coy commanders and platoons etc.) includes several areas:

Managers' leading function - it is a way / approach how a manager coordinate subordinate group of employees (himself led team). Basically this function should be realized with the regard on task organization achievement with the methods in order to positively affect creative problem solving accomplishment (Performance of the tasks by the subordinate management).

Managers' planning function - it depends and it is result of level leading skills of manager. In principle this function should support tasks accomplishment of organization.

Managers' organizing function - it depends and it is result of level leading skills of manager. It should always contribute to effective organization activities.

Managers' function within human resources area - main goal should be always to achieve assurance that managers' but not only managers' positions are occupied by the qualified employees able and willing to fulfil company aims.

Managers' control function - main goal at all times is to achieve assurance that plan is successfully realized.

Commanders at the all level of the command during their leading activities should apply following persuasion and principles for the leading of subordinates and for the unit task accomplishment under their command. For the task fulfilling commander - manager use these principles:

Principle of objective conformity - more managers are able to harmonize personal aims of individuals with aims of organization then organization will be more effective and efficient.

Principle of motivation - it is not only simple matter of reasons and consequences. That is why managers will judge more preciously system of extra pay (with consideration to the current situation) and they will implement it more into the whole system of leading and motivation program would be more effective.

Leadership principle - people have a tendency follow person diffusing atmosphere, skills and resources to satisfy their personal goals.

Clear communication principle communication would be simpler if the way of communication, language and the manner of transmission to recipient is more obvious. Originator is responsible for the clear and understandable message formulation.

Communication integrity principle - better and sophisticated integration and consistence written, verbal and nonverbal communication also moral behaviour from originator make contents more acceptable by the recipient.

Supportive application informal organization principle - communication would be more effective if managers use more informal organizational structure to support communication channels of formal structure. Managers should use this instrument for completing of inaccessible information and for providing of information in the situation of unavailable information from the formal communication system. 
Authors Saliger, Pindešová and Pokorný (2008, 2010) based on analysis of environment requirements NNEC present that competency model of the military professionals (managers commanders) includes:

\section{a) Core competency:}

To understand a meaning and share (communicate) meanings and values, perceive the context and usefully be in context, system and process, to think critically, to create recognition, to make decisions and act.

\section{b) Part competencies:}

1. To use different processes andsituational contexts for a conscious development of one's abilities and resources. Competency also includes the ability to learn, evolve and to create one's abilities and abilities of the system (team).

2. To think creatively, create recognition and appraise the knowledge, responsively adapt for the environment and make decisions. Perceive the change as a basic and natural part of life, profession and the world. Evolve the ability of perceiving, suggesting and realizing of changes. 3 . To consciously, usefully in regards to given context, use own sources and sources from one's environment to reach the meaning, values and given objectives. To orientate in social, information and communication systems, to be able to competently exploit them and to be able to establish stable supporting grounds.

4. Constantly reflect on specifics of military and managerial professions and military activities in organizational, systematic and social continuum.

Competence includes:

- To transform knowledge of the importance of sharing (communicating) to an evolution of one's own communicational abilities.

- To cope with the burden of change and to enhance this ability min a team or a system.

- To cultivate useful standing competencies and to progress in new sources and competencies. Priority is a flexibility in expertise for different contexts (expert, commander, member of a team) which allows to utilize every situational context, a change to evolve ourselves, our team or a system in a sense of reaching object ability or an effect.

5. To be beneficial member of a team or a system and to lead and take care of the team or a system in various situational contexts.
Competence includes:

- Ability to define usefulness of one's own competencies and activities and to include them to the context of working in a team or a system. - Ability to lead people to a common goal, to support and help them.

Aforementioned competence model is meant as a framework, which formulates qualities useful for survival and evolution of an individual in a system and an environment in every possible situational context.

Criteria for competence quality and professionals' abilities rise in general. Following conclusions can be identified from an NNEC analysis' results:

a) rise in input criteria - qualification presumptions;

b) rise in requirements on cognitive abilities values of all professionals;

c) rise in requirements on general intelligence level, professional readiness and professional specialization.

General requirements on abilities of all military professionals can be characterized subsequently:

1. Ability to keep situational awareness.

Examples of parameters satiating the criteria:

a) Pointers of effective capacity of one's mind, insight and creativity and related abilities and functions.

b) Understanding of certain situations; Independent judgment; Systematic reasoning.

c) Concentration and persistence of awareness.

2. Ability to adapt, to actively and creatively implant.

Examples of parameters satiating the criteria:

a) Adaptability to changes; Prediction of changes; Creativity in processing and managing of changes.

b) Objectively evaluate situations and options; Adapt to reality; adequately react; Adapt in informational and communicational environment.

3. Ability to make decisions in situations with multiple choices connected with unpredictable outcomes.

Examples of parameters satiating the criteria:

a) Resolve and responsibility for one's decisions and actions.

b) Orientation in situations with multiple outcomes.

c) Ability to formulate goals, objectives and means to reach them.

4. Mental durability. 
Examples of parameters satiating the criteria:

a) Change and stress management; Reaction to stress; Resistance to frustration; Ability of self-control.

b) Means of dealing with stress situations effectiveness of stress management; Control of situation and reactions.

5. Ability to regulate one's own inner and outer activity (actions) in regards to actual situational contexts.

Examples of parameters satiating the criteria:

Ability to take risks adequate to a situation; Ability to control emotions $[5,6]$.

\section{Role of manager in process of command and control}

Functions of manager are typical function which leader-manager uses within his work. This conception of view could be sometimes softened by opinion, that functions of manager are key knowledge, which is must for the leader-manager to deal with his area of responsibility at work. It is based on assumption, that the best way to fulfill visions of organization, fulfilling the meaning of manager's work included, is to harmonize specific functions of manager. Not even World goes through changes, but even environment does so. Many experts are convinced that organizations are going to go through important changes, which will affect the management importantly.

Managers (commanders) of the 21.st century are more often forced by cuts in budgets to work with petty working teams, which will definitely lead to lose jobs for many soldiers, even to lose their loyalty to be a good soldier. Weakening of guarantees of long term employment affects negatively also loyalty to organization of top managers, middle managers and operations manager too. Reducing the number of employees leads even to change in organization's structure, especially to reduction of number in controlling levels. It simultaneously affects the character of planning, organizing, leading, staffing and controlling process of middle and operations managers.

In this situation units will need more and more managers, who don't use authoritarian leadership, but rather act as a coordinators, leaders and coaches. There is no way, especially in the army, to resign to use of basics of management instead of coordination.
Nevertheless, it could be assumed, that the style of leadership will be definitely based on experience of commander (manager) and his superiors. It could be also expected, that the profession of commander will not disappear in the close future, and will be more oriented to commander's ability as a leader within the organization structure of the army, and commander will subject to many requirements in relations to competence listed above.

\section{Conclusions}

Generally, the commander (manager) as a representative of an organization is crucial representative and spokesman with superiors and subordinates. In the partial role of the leader is the main person to lead the team of colleagues in the unit, which he can more or less staff, organize, coordinate, motivate, stimulate and meaningfully develop their professional and qualification profile by himself. In the partial role is even link and intermediary of information transfer and contacts.

We all feels that the success in leadership is not based on obeying the rules, but is more based on changing the rules to fit the situation. It looks like that the capabilities of commander are in many cases come from desire to rule own life and working environment, more than from any moral principle. People who have power over other people need some socially acceptable justification to found their power legitimate.

According to Machiavelli, means used by rulers are justified if everything goes well for them. However, to convince the people, ruler must be seen as an altruist. It is clear that this principle, to sell the idea, convince others, look like someone who cares, is indispensable political action. It is said, that it is insincerity of others, that ruler, who acts every time according to his clearest intentions is trapped and loses his power. This hypocrisy was hated by Socrates, who has believed, that the attempt to convince audience by eloquence to agree with something, which is not true, is dishonest act and dishonesty is always unacceptable. The moral order for today's informational society must yet to be created. What could be found, with high level of confidence, as a leading principle is consensus of agreement - the form of democracy, which must manager (commander) use, to get support from his subordination? 


\section{References}

[1] DONNELLY Jr., J. H., GIPSON, J. L., IVANCEVICH, M.: Management, GRADA Publishing, 1997. ISBN 80-7169-422-3.

[2] VODÁČEK, L., VODÁČKOVÁ, O.: Management: Teorie a praxe $v$ informační společnosti, 3. Vydání, Praha: Management Press, 1999. ISBN 80-85943-94-8.

[3] TYSON, S., JACKSON, T.: Organizační chování, Grada Publishing, 1997. ISBN 807169-296-4.

[4] WEIHRICH, H., KOONTZ, H.: Management. Praha: Victoria Publishing, A. G., 1993. ISBN 80-85605-45-7.

[5] SALIGER, Radomír, PINDEŠOVÁ, Eva a POKORNÝ, Vratislav. Trendy zkoumání a modely pro rozvoj schopností, kvalit kompetencí lidí a lidských systémů pro prostředí NATO Network Enabled Capability, v profesní př́ípravě (vzdělávání a výcviku). In Sborník přednášek z 2. mezinárodního kongresu Interop-Soft Protect [CD-ROM]. Brno: 17s., 2008. ISBN 978-80-7392-023-4.

[6] SALIGER, Radomír, POKORNÝ, Vratislav a PINDEŠOVÁ, Eva. Kognitivní management. Brno: Univerzita obrany, 173s. 2010. ISBN 978-80-7231-768-4. 